\title{
Unleashing the Potential of Artificial Intelligence (AI) in Customer Journey of Cognitive Marketing and Consciousness Intention in E-Commerce Websites
}

\author{
Durga Madhab Mahapatra ${ }^{1}$ Soumendra Kumar Patra ${ }^{2}$ Sukanta Kumar Baral ${ }^{3 *}$ \\ ${ }^{1}$ Lecurer, PG Department of Commerce, FM Autonomous College, Balasore, Odisha, India \\ ${ }^{2}$ Sr. Assistant Professor, Department of Business Administration, Ravenshaw University, Cuttack, Odisha, India \\ ${ }^{3 *}$ Professor, Department of Commerce, Faculty of Commerce \& Management, Indira Gandhi National Tribal \\ University (A Central University), Amarkantak, Madhya Pradesh, India \\ *Corresponding author E-mail: drskbinfo@gmail.com
}

\begin{abstract}
Serendipitously, digital innovations have entered the entire ICT basket, which includes computers, tablets, and mobile phones. Instead of using physical networks, wireless and Wi-Fi networking is seen to represent a new generation of technology. Technology is an enabler, which can be used to customise and personalised customer choice in terms of consciousness and intention to purchase by rich texts about product, new interactive images, interactive videos, good audios, sites. Through cognitive and affective indentations to purchase in the ECommerce websites. Technology is the tomorrow's new dawn. Also, change is inevitable and desirable. Change in fact has been forced upon us to adopt new technology. Artificial Intelligence (AI) is one among them, which has been created by humans to think and react like one of us but with a more accurate performance. This paper is focussed to understand how far Artificial Intelligence makes it successful in behaviour of the customer's consciousness intention to purchase and customer journey in cognitive marketing. The study mainly focuses on customers of twin city of Odisha. The results of the study showed that AI and Customer Experience have a positive, meaningful relationship.
\end{abstract}

Keywords: E-Commerce, Artificial Intelligence, Consciousness, Cognitive Marketing.

\section{INTRODUCTION}

India has undergone a massive transformation in its economy, society and policy during this millennium to reach $\$ 5$ trillion economy by 2025 . Technological changes, especially the universal reach of mobile telephony, digital identity in Aadhar and reduced data costs have expedited India's rise in digital curve. The Technology has massively impacted every aspect of our lives over the past 30 years. Lakhmraju, Mohan (2017) India's youthful demographic which has exerted an aspiration pull in our economy, with society yearning for better education, health, ease of living and doing business. Technology has changed and is continuing to change the way banking is conducted. Many developing technologies are quickly transitioning from "technologies to observe" to "technologies to implement". There are eight disruptive technologies that are the most important. As a result, (a) data management, (b) cloud ERP and EPM, (c) blockchain, (d) robotic process automation, (e) machine learning, (f) cognitive technologies, (g) natural language processing, and (h) digital analytics and delivery are all important. Technology will bring changes at an exponential leave and at an unfathomable speed and scale. Technology is opening up new frontiers but it is also presenting new challenges that the world must conform. The platform of Digital customer experience, in which different technologies such as cloud, AI, video streaming and hosting are married to create an ecosystem. 


\subsection{Historical Background of Artificial Intelligence (AI)}

Table 1: Background of Artificial Intelligence (AI)

\begin{tabular}{|c|c|}
\hline Year & Developments \\
\hline $\begin{array}{l}\text { 1940-50 } \\
\text { The Birth } \\
\text { of AI }\end{array}$ & $\begin{array}{l}\text { Alan Turning developed the Turning } \\
\text { Test in } 1950 \text { as a technique of testing if } \\
\text { a computer is capable of thinking like a } \\
\text { human person. }\end{array}$ \\
\hline $\begin{array}{l}\text { 1956-1974: } \\
\text { The } \\
\text { Golden } \\
\text { Years }\end{array}$ & $\begin{array}{l}\text { In 1956, during a symposium held at } \\
\text { Dartmouth College, the term "artificial } \\
\text { intelligence" was coined. }\end{array}$ \\
\hline 1961 & $\begin{array}{l}\text { To defeat humanoid players, Samuel's } \\
\text { Checkers software employed -Machine } \\
\text { learning. }\end{array}$ \\
\hline 1966 & $\begin{array}{l}\text { The IBM Shorbox performed } \\
\text { arithmetic using voice commands. The } \\
\text { Shakey was the first mobile robot to be } \\
\text { conscious of its surroundings. MIIT's } \\
\text { AI Laboratory developed ELIZA, an } \\
\text { artificial conversational "therapist". }\end{array}$ \\
\hline 1974-1980 & $\begin{array}{l}\text { During 1978, programmes such as R1 / } \\
\text { XCON were developed to assist sales } \\
\text { personnel in avoiding product proposal } \\
\text { mistakes. }\end{array}$ \\
\hline $\begin{array}{l}\text { 1980-1987: } \\
\text { The Boom } \\
\text { periods }\end{array}$ & $\begin{array}{l}\text { 1987-1994: Second Winter } \\
\text { 1994: Present: Modern Era } \\
\text { Two robotic cars drove long-distance } \\
\text { on the highway }\end{array}$ \\
\hline 1997 & $\begin{array}{l}\text { 1997: Deep Blue, world chess } \\
\text { champion Garry Kasparov is defeated } \\
\text { by chess-playing computer developed } \\
\text { by IBM. } \\
\text { Kismet, a friendly machine capable of } \\
\text { conveying emotions, was introduced in } \\
\text { the year } 2000 \text {. }\end{array}$ \\
\hline 2004 & $\begin{array}{l}\text { A personal Robert, Honda Asimo, was } \\
\text { produced. }\end{array}$ \\
\hline 2011 & $\begin{array}{l}\text { On Jeopardy, a long-running US game } \\
\text { show, IBM Watson defeats two of the } \\
\text { most successful human competitors. }\end{array}$ \\
\hline 2016 & $\begin{array}{l}\text { Virtual agent overview with Siri, } \\
\text { Google Now, and IP Soft's Amelia. }\end{array}$ \\
\hline 2017 & $\begin{array}{l}\text { Google's Auto ML technology allows } \\
\text { AI to build AI. }\end{array}$ \\
\hline 2018 & $\begin{array}{l}\text { Google spin-off Waymo lunched self- } \\
\text { driving cars in Arizona. }\end{array}$ \\
\hline
\end{tabular}

Source: Accenture; other reports

As it is credited with a range of other shifts in existing market patterns and continues to shift sectors, technology is a major contributor to this transition. But a paradigm change has occurred with the accelerated use of technology and accounting is at the forefront of all technical developments. The leading factors are an increase in cloud technology investment and the rise of small businesses. In the country, China is the biggest cloud technology consumer, followed by India. In revolutionising the profession, the new block chain technology will also play a major role in freeing accountants from daily bookkeeping practises and offering greater transparency about an organisation's finances and obligations. Ernst Young, Price Waterhouse, KPMG and Deloitte are the Big Four in the accounting sector, leading the trend towards recognising the accounting block chain.

Table 2: Internet penetration $\%$ wise population (India's position is '9')

\begin{tabular}{|l|l|l|}
\hline Country & $\begin{array}{l}\text { Internet } \\
\text { penetration \% } \\
\text { of population }\end{array}$ & $\begin{array}{l}\text { Nos. } \\
\text { (In } \\
\text { Million) }\end{array}$ \\
\hline Africa & 39.60 & 522 \\
\hline Asia & 54.20 & 2.3 \\
\hline Europe & 87.70 & 726 \\
\hline Latin America & 68.90 & 453 \\
\hline Middle America & 67.90 & 176 \\
\hline North America & 89.40 & 328 \\
\hline Australia & 68.40 & 29 \\
\hline China & 58.40 & 829 \\
\hline India & 40.90 & 560 \\
\hline World & 58.80 & 4.54 \\
\hline
\end{tabular}

Source: Internet world status, The Economic Times 3rd September 2019, p-10

Another big technological wave, Artificial Intelligence (AI), is here to stay and develop in the future by leaps and bounds as it can perform the most complicated tasks without a monthly salary overhead. For any company wanting to adopt this technology, an overhaul of the accounting department, leading to systemic improvements, is a necessity as it increases efficiency and accuracy and decreases expenses. There are different ways in which AI can help enhance the function of accounting. First, as AI gathers data from various agencies, gathers and merges it in no time, the reconciliation process is quicker and free of errors. Second, AI leads to paperless procurement and better control of vendors. Third, with the aid of automated workflow, creditor / debtor management is streamlined. Moreover, digitisation of accounting documents ensures that the audit feature is better usable and accurate. And lastly, with the assistance of AI, cost control is smooth, which can also help answer some of the users' frequently asked questions. A Sage survey reveals that $66 \%$ of accountants were prepared to invest in AI. In addition, the Internet is typically included, but text messaging by wireless, 
instant messaging, mobile apps, podcasts, electronic signs, digital TV and radio networks, and other services are frequently included in this context. In recent years, mobile and internet innovations have refined the manner in which e-commerce websites are distributed.

Table 3: Major global players of AI (Artificial Intelligence)

\begin{tabular}{|l|l|}
\hline Company & $\begin{array}{l}\text { Name of AI (intelligence } \\
\text { personal assistants) }\end{array}$ \\
\hline Google & Google Assistant \\
\hline Apple & Siri \\
\hline Amazon & Alexa \\
\hline IBM & Watson assistant \\
\hline Microsoft & Cortana \\
\hline Blackberry & Blackberry assistant \\
\hline Nuance & Nina \\
\hline Cognitive code & Silvia \\
\hline Samsung & Bixby \\
\hline
\end{tabular}

Source: Business Standard, 3rd September 2019, p.15

Cognitive development, such as the cognitive functioning of (a) mental perception processes, (b) memory judgement, and (c) reasoning, as opposed to emotional and volitional processes. Cognitive technology is the general term applied to technologies capable of performing certain tasks, including the identification of handwriting, expression, or faces; language comprehension; planning; partial or ambiguous knowledge reasoning; and learning. Further, the Cognitive marketing means how a consumer attached with different perspectives through brands [Rup et al. 2018, 2021]. In addition, resource management is another field in which cognitive technology can help enhance productivity and minimise costs. Applications of cognitive technology may capture, analyse and send real-time information to producers of consumer goods to help them handle inventory and fulfil orders more effectively. In how (a) consumers discover, (b) pick, (c) buy, (d) get, (e) use, and (f) get help with consumer products, cognitive technologies are intended to play a larger role. These innovations open up vast possibilities for e-commerce websites for any consumer goods to make the approach and smoother technique of consumer life easier, to reduce confusion and improve trust in purchases, and to help customers rejoice in and even connect with products as well as searching for e-commerce websites. The E-Commerce websites which have been ahead of the curve in using AI, ML, Deep Learning, Enterprise Data -Lake technological advances to deliver services to consumers. The consumer benefited from hassle-free use of channels more tailored products, services and better response time. (Biswal, Manas Ranjan. (2020)

\section{REVIEW OF LITERATURE}

The digital revolution, according to Hosanagar, Kartik. (2020), has taken over the current world. "AI has enormous potential for automation and digital transformation in a variety of industries". "In terms of AI use, India is well behind China and the United States".

The relevance of AI in customer experience was discussed by Oracle (2017). "AI brings consumer data to life" by "using machine intelligence to examine through, analyse, learn from, and comprehend vast amounts of data in ways that mere mortals cannot". The use of artificial intelligence (AI) to improve the entire consumer experience.

Klein et al. (2017) conducted a research on key trade (retail) executives to examine the effect and impact of AI technology on changes in consumer engagement.

Lemon and Verhoef (2016), stated AI can be used to track the feelings of consumers. There are three stages in the consumer journey: the pre-purchase process, the purchase process, and the post-purchase phase. Identification of a need, searching, and the construction of a collection of considerations based on exposure to web-based knowledge, advertising, user-generated material, word of mouth, or other stimuli are all part of the first step. Customers choose what they want in the second step and proceed with the payment depending on the information provided. The third stage is characterised by behaviours such as use and consumption, and phenomena of positive or negative post-purchase engagement.

McColl-Kennedy et al. (2019) established a very popular conceptual framework for assessing and interpreting the consumer experience that considers the consumer's perspective, including emotions such as excitement, affection, surprise, frustration, sadness and fear etc. and cognitive reactions to the various touch points such as grievances, compliments, suggestions etc. that occur during the purchasing decision journey. Especially, they suggest using a text mining model based on linguistics to collect user information that are critical for making marketing decisions.

The frequency with which any image, video, or other content is posted on any Digital Marketing platform has an effect on a company's online 
marketing strategy, according to Kalpana Chauhan and Anandan Pillai (2013).

Yi-Shun Wang (2001) for web sites that sell digital goods and services, a systematic model and tool for measuring customer information satisfaction (CIS) has been developed. Important progress has been made in creating a general method to assess consumer satisfaction with the marketing of digital goods and services on websites.

\section{OBJECTIVES OF THE STUDY}

Technology is the tomorrow's new dawn. Change is inevitable and desirable. Change in fact has been forced upon us adopt new technology in different sector. Artificial Intelligence (AI) is composed to disrupt our creation. Smart Tech is also changing the face of manufacturing while the 3rd industrial revolution was about mass production, the 4 th revolution referred to as Industry 4.O; is focussed mass customisation and efficiency. Through the Internet of Things (IoT), Artificial Intelligence (AI), and Machine Learning (ML), it also allows for a speedier integration of automation into everyday activities (Machine Learning). The following are the goals of the study that was conducted to meet the research objectives:

a) To explore the factors related E-commerce websites of Amazon and Flipkart with respect to searching product by consumer consciousness intention.

b) To find the factors which are significantly influence through Artificial intelligence with respect to twin city of Odisha.

c) On the basis of the study's findings, to offer appropriate improvement strategies.

\section{RESEARCH METHODOLOGY}

Finally, the consumer consciousness intention as regards to searching the products of lifestyle by the twin city of Odisha was measured. All of the items were valued on a 5-point Likert scale, with 1 being "strongly disagree" and 5 being "strongly agree". After that, the data was entered into SPSS and analysed using structural equation modelling (SEM) using AMOS 23.0.

\section{ANALYSIS AND DISCUSSION}

The following Table no.4 illustrates the demographic profile of the respondents in the sample $(\mathrm{N}=542)$. Out of the total respondents, majority of the respondents are females (54.70 percent) and Males (45.30 percent) respectively. Furthermore, the bulk of the responders are between the ages of 26 and 30 (49.60 percent) then coming 31 to 40 years (23.10 percent), while 22.40 percent belongs to below 25 years. Few of the respondents belongs to 41 years and above (4.90 percent). With regard to qualification of the respondents, majority are having bachelor degree (34.50 percent) then coming high school (29.20 percent) and few of the respondents are belongs to diploma (19.40 percent) and post graduate (16.90 percent).

Finally, the demographic profile shows majority of the respondents (25.40 percent) are having income 30,000 to 45,000 then coming more than 45,000 rupees ( 25.40 percent) and then coming less than 15000 rupees (17.20 percent) respectively. Few of the respondents are having monthly income from 15,000 to 30,000 (5.40 percent). The research also focuses on the influence of website ads on consumer purchasing behaviour, which increases the intentions of the consumer towards the product and purchasing behaviour. The ads of the website affected customer buying decisions to a modest degree as only approximately half of respondents were affected by market recognition purchases through internet advertising. Consumers do not purchase goods; rather, they purchase reasons to be fulfilled or to resolve problems.

Table 4: Demographic Profile of the respondents $(\mathrm{N}=542)$

\begin{tabular}{|c|c|c|c|}
\hline Particulars & Category & Frequency & Percentage \\
\hline \multirow{2}{*}{ Gender } & Male & 246 & 45.3 \\
\hline & Female & 296 & 54.7 \\
\hline \multicolumn{2}{|r|}{ Total } & 542 & 100 \\
\hline \multirow{4}{*}{ Age } & $\begin{array}{l}\text { Below } 25 \\
\text { years }\end{array}$ & 121 & 22.4 \\
\hline & $\begin{array}{l}26 \text { to } 30 \\
\text { years }\end{array}$ & 269 & 49.6 \\
\hline & $\begin{array}{l}31 \text { to } 40 \\
\text { years }\end{array}$ & 125 & 23.1 \\
\hline & $\begin{array}{l}41 \text { years and } \\
\text { above }\end{array}$ & 27 & 4.9 \\
\hline \multicolumn{2}{|r|}{ Total } & 542 & 100 \\
\hline \multirow{4}{*}{ Qualification } & High school & 158 & 29.2 \\
\hline & Diploma & 105 & 19.4 \\
\hline & $\begin{array}{l}\text { Bachelor } \\
\text { (UG) }\end{array}$ & 187 & 34.5 \\
\hline & $\begin{array}{l}\text { Postgraduate } \\
(\mathrm{PG})\end{array}$ & 92 & 16.9 \\
\hline \multicolumn{2}{|r|}{ Total } & 542 & 100 \\
\hline \multirow{4}{*}{$\begin{array}{l}\text { Monthly } \\
\text { income }\end{array}$} & $\begin{array}{l}\text { Less than } \\
15000\end{array}$ & 94 & 17.2 \\
\hline & $\begin{array}{l}15001- \\
30,000 \\
\end{array}$ & 29 & 5.4 \\
\hline & $\begin{array}{l}30,001- \\
45,000\end{array}$ & 281 & 52 \\
\hline & More than & 138 & 25.4 \\
\hline
\end{tabular}




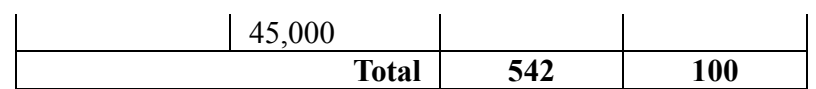

Source: Developed from the survey data

After profile analysis of the respondents, further analysis was undertaken to examine the reliability of the twenty-three related to potential of artificial intelligence in customer journey towards Ecommerce websites variables. Reliability analysis i.e., Cronbach's alpha $(\alpha)$ was applied. Reliability analysis was conducted after screening of data and replacing missing values by SPSS software. Shopping is their primary source of enjoyment, and they identify it with leisure and lifestyle activities. The Consumers are becoming highly green conscious about searching the websites. Technologies such as (a) Affective Computing, (b) Emotion AI can bring in a good experience by integrating data-driven interactions that represent modern Human Centered Design (HCD) techniques that encourage deep emotional connexions across ecommerce websites with products and brands, which in turn can drive loyalty and business activities in line with growth. Contextually relevant content is necessary to operationalize the customer experience on a scale.

Table 5: Descriptive and Reliability Analysis (N= 542)

\begin{tabular}{|c|c|c|c|c|c|}
\hline$\dot{\omega}$ & 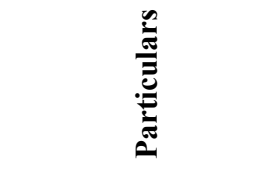 & 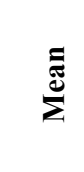 & 语 & 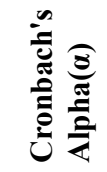 & 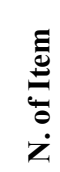 \\
\hline 1 & $\begin{array}{l}\text { Potential of } \\
\text { Artificial } \\
\text { Intelligence (AI) in } \\
\text { Customer Journey } \\
\text { of Cognitive } \\
\text { Marketing. }\end{array}$ & 4.231 & 0.237 & 0.875 & 23 \\
\hline
\end{tabular}

Source: Developed from the survey data

The Alpha value of combined is coming more than 0.80 , reveals all the items in the questionnaire are reliable. Therefore, it can be inferred, based on the alpha outcomes of the Cronbach, that the measurement items achieved acceptable reliability. Artificial Intelligence (AI) is expected to alter both marketing tactics and consumer habits dramatically. $\mathrm{AI}$ is anticipated to have an influence on marketing strategies, including company models including sales procedures and customer care options, as well as consumer behaviour, for example, text, speech, images, or facial expressions. (Kaplan and Haenlein 2019, p. 17). Further, customer friendliness remains open to feedback and responsive that enabled for Ecommerce websites to deliver and improve services.
Table 6: Factor loading of items (AI)

\begin{tabular}{|c|c|}
\hline Items and Construct & $\begin{array}{l}\text { Factor } \\
\text { loadings }\end{array}$ \\
\hline \multicolumn{2}{|c|}{ Customer Demand Anticipation (CDA) } \\
\hline $\begin{array}{l}\text { This AI carries high quality of } \\
\text { Customer consciousness. }\end{array}$ & 0.830 \\
\hline $\begin{array}{l}\text { This AI provided the Demographic } \\
\text { shifts. }\end{array}$ & 0.510 \\
\hline $\begin{array}{l}\text { This AI offers to the consumers in } \\
\text { variety of products and services. }\end{array}$ & 0.540 \\
\hline \multicolumn{2}{|c|}{ Improved Inventory Management (IIM) } \\
\hline $\begin{array}{l}\text { The supply chain can be traced out } \\
\text { through AI. }\end{array}$ & 0.850 \\
\hline $\begin{array}{l}\text { The delivery services and put signature } \\
\text { of the consumer can easily trace out } \\
\text { through AI. }\end{array}$ & 0.580 \\
\hline $\begin{array}{l}\text { The reaching to the perspective } \\
\text { consumer and reverse purchase with } \\
\text { same websites will be thoroughly } \\
\text { evaluated by AI. }\end{array}$ & 0.640 \\
\hline \multicolumn{2}{|c|}{ Efficient Delivery Management (EDM) } \\
\hline $\begin{array}{l}\text { Multiple tailor-made products are } \\
\text { offered through AI }\end{array}$ & 0.800 \\
\hline $\begin{array}{l}\text { To compete with other product, the spur } \\
\text { advertisement can made successful } \\
\text { though AI. }\end{array}$ & 0.710 \\
\hline $\begin{array}{l}\text { The smaller and premium pack size } \\
\text { with self-congruity and product } \\
\text { evaluation is dealt with AI. }\end{array}$ & 0.730 \\
\hline $\begin{array}{l}\text { Thee- loyalty cues with brand trust } \\
\text { through AI. }\end{array}$ & 0.650 \\
\hline \multicolumn{2}{|l|}{ Personalized Suggestions (PS) } \\
\hline $\begin{array}{l}\text { AI shows the comparative best prices } \\
\text { for most products. }\end{array}$ & 0.760 \\
\hline $\begin{array}{l}\text { AI enabled monitoring of transactions } \\
\text { are managing grid stability. }\end{array}$ & 0.680 \\
\hline $\begin{array}{l}\text { The AI broadening base of digital } \\
\text { access. }\end{array}$ & 0.930 \\
\hline \multicolumn{2}{|c|}{ Image-Based Product Search (IBPS) } \\
\hline $\begin{array}{l}\text { The Product search are frequently } \\
\text { shown. }\end{array}$ & 0.660 \\
\hline $\begin{array}{l}\text { The Seasonal promotions are in use by } \\
\text { AI. }\end{array}$ & 0.560 \\
\hline $\begin{array}{l}\text { Comparative Prices are shown in } \\
\text { through AI. }\end{array}$ & 0.840 \\
\hline \multicolumn{2}{|c|}{$\begin{array}{l}\text { Early Identification of Potential Consumer } \\
\text { (EIPC) }\end{array}$} \\
\hline $\begin{array}{l}\text { The sentiment of the customer can be } \\
\text { identified through AI. }\end{array}$ & 0.480 \\
\hline $\begin{array}{l}\text { The Web analytics can find the } \\
\text { potential consumer through AI. }\end{array}$ & 0.880 \\
\hline $\begin{array}{l}\text { The value-add services focussed the sub- } \\
\text { conscious mind of the consumer through AI. }\end{array}$ & 0.940 \\
\hline
\end{tabular}




\begin{tabular}{|l|c|}
\hline \multicolumn{2}{|c|}{$\begin{array}{c}\text { Automating and Expediting Administrative } \\
\text { Tasks (AEAT) }\end{array}$} \\
\hline The website is dynamic. & 0.650 \\
\hline $\begin{array}{l}\text { The effect of Design of the websites is } \\
\text { influence the consumers through AI. }\end{array}$ & 0.530 \\
\hline $\begin{array}{l}\text { The listing of the Product with different } \\
\text { segment can put forth with AI. }\end{array}$ & 0.740 \\
\hline $\begin{array}{l}\text { The role of SEO is carrying out the } \\
\text { website listing through AI. }\end{array}$ & 0.660 \\
\hline
\end{tabular}

Source: Developed from the survey data by the Authors

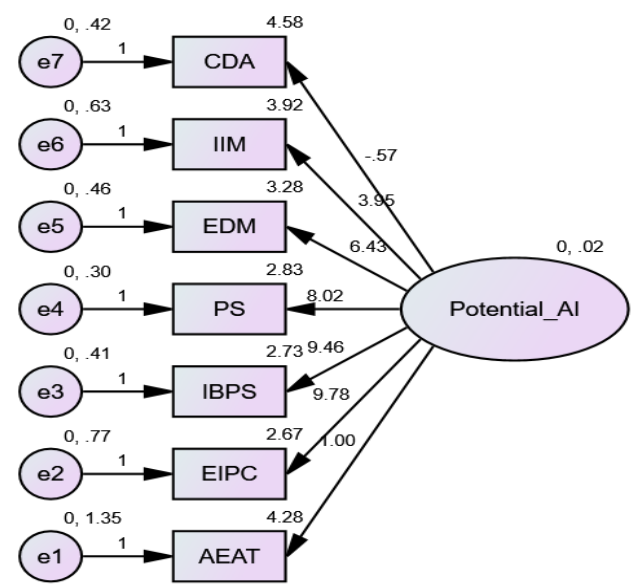

Fig.1: SEM of Potential AI

CDA: Customer demand anticipation; IIM: Improved inventory management; EDM: Efficient delivery management; PS: Personalized suggestions; IBPS: Image-based product search; EIPC: Early identification of potential consumer; AEAT:Automating and expediting administrative tasks.Group number 1 (Group number 1 - Default model)Estimates (Group number 1 - Default model)Scalar Estimates (Group number 1 - Default model)

Table 7: Summary SEM results of Potential of AI

\begin{tabular}{|c|c|c|c|c|c|}
\hline Particulars & CFI & NFI & GFI & RMSEA & RFI \\
\hline $\begin{array}{l}\text { Chi-square } \\
=227.477\end{array}$ & \multirow[b]{3}{*}{0.915} & \multirow[b]{3}{*}{0.912} & \multirow[b]{3}{*}{0.918} & \multirow{3}{*}{0.085} & \multirow[b]{3}{*}{0.910} \\
\hline $\mathrm{df}=14$ & & & & & \\
\hline $\begin{array}{l}\text { P value = } \\
0.000 \\
\text { (Probability } \\
\text { value/ } \\
\text { significant } \\
\text { value) }\end{array}$ & & & & & \\
\hline
\end{tabular}

Source: Developed from the survey data (Primary)

df: degrees of freedom; CFI: Comparative fit index; NFI: Normed fit index; GFI: Goodness - of- fit; RFI: Relative fit index; RMSEA: Root Mean Square Error of Approximation.

The table above depicts the SEM model fitness structure in terms of AI potential. The results of the above table show that all of the AI elements are closely linked. According to the model, each indicator variable loaded significantly with its intended construct, which was properly fitted and evaluated. In the SEM model, Chi-square $=227.477$, df $=14, \quad \mathrm{p}<0.001, \quad \mathrm{CFI}=0.915, \quad \mathrm{GFI}=0.918$, $\mathrm{NFI}=0.912, \mathrm{RFI}=0.910, \mathrm{RMSEA}=0.085$, provided a good fit to the data (Browne and Cudek, 1993; Hu and Bentler, 1999). Further, as far as customer experience, security and stability are disadvantages. A buyer can $\log$ in to the website or app of the company, fill in details such as location, language of choice and requirement. Further, people are more comfortable in shopping via video streaming that scaling up to cater to their requirements. It focuses entire sequence of documentation. It's also becoming popular as brick-mortar stores at away to stay competitive world. The personalised buying experience can make it successful through Artificial intelligence which a cause a big leap in terms of tech like the internet changed things in the last decade. (Ahmad, Samreen (2020). The predictive behavioural indicators and periodic verification also put a right direction towards to identify location data and based on the location data for gathering more information.

Table 8: Regression Analysis of Variable (Potential of AI)

\begin{tabular}{|c|c|c|c|c|c|c|}
\hline \multicolumn{3}{|c|}{ Particulars } & Estimate & S.E. & C.R. & $\begin{array}{r}P \\
\text { Label }\end{array}$ \\
\hline AEAT & $<---$ & $\begin{array}{l}\text { Potential } \\
\text { of AI } \\
\text { Potential }\end{array}$ & 1.000 & & & \\
\hline EIPC & $<---$ & $\begin{array}{l}\text { of AI } \\
\text { Potential }\end{array}$ & 9.778 & 3.299 & 2.964 & $* * *$ \\
\hline IBPS & $<--$ & $\begin{array}{l}\text { of AI } \\
\text { Potential }\end{array}$ & 9.461 & 3.188 & 2.968 & $* * *$ \\
\hline PS & $<---$ & $\begin{array}{l}\text { of AI } \\
\text { Potential }\end{array}$ & 8.020 & 2.702 & 2.968 & $* * *$ \\
\hline EDM & $<---$ & $\begin{array}{l}\text { of AI } \\
\text { Potential }\end{array}$ & 6.428 & 2.171 & 2.961 & $* * *$ \\
\hline IIM & & $\begin{array}{l}\text { of AI } \\
\text { Potential }\end{array}$ & 3.949 & 1.348 & $\begin{array}{r}2.930 \\
-\end{array}$ & $* * *$ \\
\hline CDA & $<---$ & of AI & -0.566 & 0.267 & 2.116 & $* * *$ \\
\hline
\end{tabular}

The above table shows the results of regression model derived through SEM. As shown in the above table, all the $\mathrm{p}$ value of the contributing variables related to the potential of $\mathrm{AI}$ in E-commerce websites was accepted since the significant value of $p$ is coming $* * *(<0.05)$. The path analysis demonstrates that the aforementioned model's regression weights 
are structurally fit. In addition, all of the contributing elements to the factor (Potential of AI) are statistically significant and contribute to the SEM. Out of the seven derived factors, the factor "EIPC: Early identification of potential consumer (9.778) is contributing maximum towards potential of AI in Ecommerce websites. Then coming the factor "IBPS: Image-based product search (9.461)" since estimated value of the regression weights is coming highest. Further, the factor - $\boldsymbol{C D A}$ : Customer demand anticipation (-0.566) though coming significant $(* * *)$ but negatively associated with potential of AI in Ecommerce websites. Since, AI will not work in anticipation of demand, the factor is coming negative impact though it is coming significant.

\section{CONCLUSION}

The constant growth in consumer expectations has made improving the customer experience a difficult challenge for businesses. Companies that want to achieve a competitive advantage in customer service should think about more than just delivering content on the right channel at the right time. AI provides the organisation with an awareness of the clients, helping organisations to prepare strategies accordingly. Forrester's 2016 global state of AI online survey Legget states that AI is now increasingly employed by many firms to increase the personalised customer experience, demonstrating that customer service is presently one of the most important sectors in the investment and adoption of AI systems. Virtual Personal Assistants (VPAs) like Bixby, Alexa (Amazon), Siri (Apple), and Cortana (Microsoft) are at the forefront of commercially viable artificial intelligence (AI). Artificial intelligence (AI) is the use of technological systems to do tasks that would otherwise be done by people."Consumers will be delighted by AI's ability to make these conversations natural and active, predicting needs based on context, preferences, and previous inquiries; providing advice, resolutions, notifications, and offers; and learning over time." according to the statement.

\section{REFERENCES}

[1] B.K., Rup, J. Gochhayat, S. Samanta, Revisiting Brand Personality Attributes: Mediating Role of Brand Attitude. International Journal of Asian Business and Information Management $\begin{array}{llll}(\mathrm{IJABIM}) & \text { 12(2) } \quad \text { (2021) }\end{array}$ http://doi.org/10.4018/IJABIM.20210401.oa8

[2] B.K., Rup, J. Gochhayat, S. Samanta, Role of Biological Sex and Gender Roles on Perceived
Brand Personality, International Journal of Knowledge-based and Intelligent Engineering

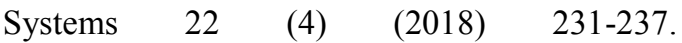
DOI: $10.3233 / \mathrm{KES}-180387$

[3] Hosanagar, Kartik (2020). AI a job killer or creator? Business Today, 28th Anniversary Issue, 9th February 2020, pp.120-124.

[4] Kalpana Chauhan, A. P. (2013). Emerald Insights. Retrieved on 17th July, 2019 from https://www.emerald.com/insight/content/doi/10 .110 8/10610421311298687/full/html

[5] Klein, R., Parsons, D., Sonsev, V., Peetermann, L(2017). How AI Technology Will Transform C ustomer Engagement (Rep.). Retrieved from: https://communications network.letslinc.com/wpcontent/uploads/2017/07/ Linc_BrandGarage_Customer-Service-and-AI-Report.pdf.

[6] Lakhmraju, Mohan (2017). Technology and taller development of knowledge, Business Standard, June 2017, p.15.

[7] Kaplan, A., \&Haenlein, M. (2019). Siri, Siri, stylish my help:

Who's the unprejudiced uptodate the land? On the understanding, example, and union of person who acts automatically understand. Business Horizons, 62(1), https://link.springlike.com/article/10.1007/s117 47-019-00696-0.

[7] Lemon, K. N., \& Verhoef, P. C. (2016). Understanding someone who purchases of merchandise occurrence all the while all of the someone who purchases of merchandise journey. Journal of buying, 80(6), pp. 69-96. https:// doi.org/10.1509/jm.15.0420

[8] McColl-Kennedy, J. R., Zaki,M., Lemon, K. N., Urmetzer, F. \& Neely, A. (2019). Gaining Customer Experience Insights That Matter. Journal effective Research, 22(1), pp. 8-26. https://doi.org/10.1177/1094670518812182

[9] Oracle. (2017), 5 Data-force to act Tech Trends Shaping Customer Experience (Rep.). Available from: $\quad$ http://communications network.prediction.com/united states of America of western hemisphere/ result or merchandise develop in mind or physically/ use/cx-current-ebook-3613741.pdf.

[10] Banerjee. S., Dholakia R.R. (2008). Mobile Advertising: Does Location Based Advertising 
Work?,

International Journal of Mobile Marketing,

December 2008, Vol. 3, No. 2, pp. 68-74

[11] Y. Durmaz, I.H. Efendioglu (2016). Travel from Traditional Marketing to Digital Marketing, Global Journal of Management and Business Research:

E-

Marketing, Volume 16 Issue 2, pp. 35-40.

[12] Yuniarthe, Y. (2017). Application of Artificial Intelligence (AI) in Search Engine Optimization (SEO), International Conference in contact Soft
Computing, Intelligent System and Information Technology, pp. 96-101.

[13] Ahmad, Samreen. (2020). Video buying and selling takes organ", Business Standard, 5th October 2020, p.7.

[14] Wang, Y.S. (2001). A mechanism for Measuring buyer of goods content, Journal of Electronic Commerce Research, pp.1-14.

[15] Biswal, Manas Ranjan (2020). Uniquely positioned to serve customers, The Economic Times Advertorial, $27^{\text {th }}$ December 2019, p.3. 